\section{The Bristol College of Science and Technology}

IN reply to a question in the House of Commons on June 4, Mr. Quintin Hogg, the Secretary of State for Education and Science, said that the Bristol College of Science and Technology, which is one of the ten colleges of advanced technology destined for university status following the Government's acceptance of the recom. mendations of the Robbins Report, would have to move from its present site and buildings which it shares with the Bristol Technical College. Mr. Hogg said that following a report from the Governors of the Bristol College of Science and Technology it had been decided that it should be moved to Bath, where a site has been made available for future development. Originally the plan had been to provide new buildings for the College in Bristol, but the earmarked site proved too small for the needs of an expanding university institution. Three alternatives were considered: namely, Clevedon, South Gloucestershire just outside Bristol, and Bath. It was felt that the site at Clevedon was unsuitable because of the difficult contours of much of the area, and that in South Gloucestershire did not offer the opportunities afforded by the Bath site of a close association between university and city.

\section{Return of Britain's Scientists}

IN a written answer in the House of Commons on June 18, the Secretary of State for Education and Science, Mr. Hogg, stated that most of the scientists and engineers who had so far returned from the United States and Canada in 1964 were seen by the Selection Board in 1963, when 146 candidates were recommended. Thirtyseven of those interviewed were known to have returned so far. In 1964, the Board had recommended about 190, but it was too early to say how many offers of employment would be accepted. The Board paid to candidates in North America their travelling expenses to and from the nearest place of interview and, in suitable cases, omploying departments and authorities would pay return fares to the United Kingdom of the successfully assigned candidates and their families.

\section{Advisory Committee on Pesticides and Other Toxic Chemicals}

IN a written answer on June 18, Mr. Hogg stated that following the assurance given on March 24 by the Minister of Agriculture, Fisheries and Food, the Advisory Committee on Pesticides and Toxic Chemicals had been given a new title reflecting its wide responsibilities. It would now be known as the Advisory Committee on Pesticides and Other Toxic Chemicals, and its terms of reference had been extended to keep under review all risks that might arise from the use of pesticides; potentially toxic chemicals on sale to farmers for veterinary use and veterinary medicines prescribed for use by veterinary surgeons; and any other potentially toxic chemicals specifically referred to the Committee by Ministers; and to make recommendations to the Ministers concerned. The industrial and domestic uses of organochloric pesticides were now being reviewed.

\section{Schools and Society}

Is a written reply in the House of Commons on June 16, Mr. Hogg stated that following the recommendations of the Newsom Committee for an Inter-Departmental Working Party to consider the general social problems, including education, in slum areas, an Inter-Departmental Committee had been established, with terms of reference covering these problems within a wider context. Its task would be to consider plans for, and results of, research and development work on any aspect of the general theme "The Schools and Society", with the view of the better co-ordination of activities and the more efficient use of public funds and other moneys. The Home, Health and Education Departments for England and Wales and
Scotland, the Ministry of Housing and Local Government, the Ministry of Labour and the Department of Scientific and Industrial Research were represented.

\section{National Examinations Board in Foremanship and Supervision}

Is a written answer on June 17, Mr. Hogg stated that after consultation between his Department and representatives of industry and the professional bodies chiefly concerned, including the British Institute of Management, a new National Examinations Board in Foremanship and Supervision had been set up, with as its first task consideration of the early introduction of a qualification to replace the present British Institute of Management Certificate. The Board might introduce other qualifications in foremanship and supervision if it saw the need, and he hoped to see substantially increased numbers taking courses in tho technical colleges for the Board's qualifications.

\section{A Decade of Medical Research}

IN a written answer on June 17, Sir Edward Boyle gave the estimated Government expenditure on medical research in the past ten financial years as follows: 1954-55, $£ 5.5$ million; $1955-56, £ 6.5$ million; $1956-57, £ 7$ million; 1957-58, £8 million; 1958-59, £9.5 million; 1959-60, $£ 10.5$ million; $1960-61, £ 12.5$ million; $1961-62, £ 14.5$ million; 1962-63, £16 million; and 1963-64, £18.5 million. These figures include the estimated expenditure of the Health Departments, the Medical Research Council, the General Register Office, and the Air Ministry, with the estimated proportion devoted to medical research from the general grants to universities through the University Grants Committeo.

\section{U.S. Man-power Requirements in Science, Engineering and Techno!ogy}

UNDER the titlo Scientists, Engineers and Technicians in the 1960's-Requirements and Supply, the National Science Foundation has issued a further report presenting the results of the second major investigation undertaken by the Bureau of Labour Statistics to assess these requirements in the 1960's (NSF 34. Pp. vii +68. Washington, D.C.: Government Printing Office, 1964. 45 cents). In engineering, the dermand for new personnel over the decade is estimated at more than 700,000 , of which 165,000 represents replacement and 550,000 new demands, while the number of new entrants during the period is expected to be about 450,000 . The situation will probably be particularly severe in the mid-1960's. By the end of the 1960 decade, if expenditure on the space programme levels off, and the number of engineering graduates increases more than expected, the situation may become somewhat less critical. Over the decade as a whole, the demand for engineers is expected to average about 72,000 a year compared with the projected available supply of about 45,000 . In terms of numbers, the man-power situation in the sciences is expected to be less acute, though serious: the anticipated supply of 314,000 scientists, including mathematicians, being in rough balance with a projected demand of 295,000 over the decade. This assumes that the necessary college and university facilities and faculties will be available to handle the expected almost doubled enrolments in science. Scientists in some fields are likely to be in short supply throughout the 1960's, especially chemists, physicists, and medical and biological scientists and scientists with a Ph.D. degree. The demand for tech. nicians is expected to grow at about the same rate as that for scientists and engineers, and on this basis, some 700,000 new technicians will be needed during the decade.

\section{Encouragement for Physics in the United States}

THe American Association of Physics Teachers and the American Institute of Physics are very conscious of the importance of improvement of the physics tesching in 